\title{
Mediterranean forests, land use and climate change: a social-ecological perspective
}

3 Gauquelin T. ${ }^{1}$, Michon G. ${ }^{2}$, Joffre R. ${ }^{3}$, Duponnois R. ${ }^{4}$, Génin D. ${ }^{5}$, Fady B. ${ }^{6}$, Bou Dagher M. ${ }^{7}$,

4 Derridj A. ${ }^{8}$, Slimani S. ${ }^{8}$, Badri W. ${ }^{9}$, Alifriqui M. ${ }^{10}$, Auclair L. ${ }^{5}$, Simenel R. ${ }^{5}$, Aderghal M. ${ }^{11}$,

5 Baudoin E. ${ }^{4}$, Galiana A. ${ }^{12}$, Prin $\mathrm{Y}^{13}{ }^{13}$, Sanguin H. ${ }^{13}$, Fernandez C. ${ }^{1}$, Baldy V. ${ }^{1}$

1. Institut Méditerranéen de Biodiversité et d'Ecologie - IMBE UMR CNRS - Aix Marseille Université - IRD Avignon Université, CS 80249, Case 4, Marseille, Cedex 03 13331, France

2. Laboratoire Mixte International MEDITER "Terroirs Méditerranéens" IRD, UMR GRED Gouvernance Risque Environnement Développement IRD Maroc, 15 Rue Abou Derr, BP 8967, 10000 Rabat Agdal, Maroc

3. Centre d'Ecologie Fonctionnelle et Evolutive CEFE, UMR 5175, CNRS, Université de Montpellier, Université Paul-Valéry Montpellier 3, EPHE, 1919 Route de Mende, 34293 Montpellier Cedex 5, France

4. IRD. Laboratoire des Symbioses Tropicales et Méditerranéennes-UMR 113, Campus CIRAD de Baillarguet, TA-A 82/J, 34398 Montpellier cedex 5, France

5. LPED - Laboratoire "Population Environnement Développement" UMR151 - AMU / IRD Centre St Charles, Case 10 3, place Victor Hugo13331 - Marseille Cedex 3, Laboratoire Mixte International MEDITER "Terroirs Méditerranéens" IRD.

6. INRA UR629 Ecologie des Forêts Méditerranéennes (URFM) Domaine St Paul, Site Agroparc, CS 40509, 84914 Avignon cedex 9

7. Département Sciences de la Vie et de la Terre, Université Saint Joseph Campus Sciences et technologies, Mar Roukos, Mkalles BP: 1514 Riad el Solh, Beyrouth 11072050 Liban

8. Faculté des Sciences Biologiques et des Sciences Agronomiques Université Mouloud Mammeri, B. P. N¹7 RP 15000 Tizi-Ouzou, Algérie.

9. Laboratoire Ecologie et Environnement Département de Biologie, Faculté des Sciences Ben M'sik Université Hassan II- Mohammedia- Casablanca

10. Laboratoire Ecologie et Environnement Unité associée au CNRST - URAC 32) Département de Biologie, Faculté des Sciences Semlalia Université Cadi Ayyad B.P. 2390, Marrakech, 40 001, MAROC

11. Laboratoire Mixte International MEDITER "Terroirs Méditerranéens" UM5A, E3R - Equipe de Recherche sur la Région et la Régionalisation - CERGéo, Université Mohammed V Agdal, BP: 554 RabatChellah, Rabat, Maroc

12. Laboratoire Mixte International MEDITER "Terroirs Méditerranéens" UCAM, Laboratoire Ecologie et Environnement Département de Biologie, Faculté des Sciences Semlalia Université Cadi Ayyad B.P. 2390, Marrakech, 40 001, MAROC

13. CIRAD. Laboratoire des Symbioses Tropicales et Méditerranéennes-UMR 113, Campus CIRAD de Baillarguet, TA-A 82/J, 34398 Montpellier cedex 5, France 


\section{$51 \quad$ ABSTRACT}

53 Mediterranean forests are found in the Mediterranean Basin, California, the South African Cape Province, South 54 and southwestern Australia, and parts of Central Chile. They represent 1.8\% of the world forest areas of which 55 the vast majority is found in the Mediterranean basin, where historical and paleogeographic episodes, long-term 56 human influence and geographical and climatic contrasts have created ecosystemic diversity and heterogeneity. 57 Even if evergreen are dominant, deciduous trees are also represented, with different forest types including dense 58 stands with a closed canopy (forests sensu stricto), and pre-forestal or pre-steppic structures with lower trees 59 density and height. The Mediterranean basin is also a hotspot of forest species and genetic diversity, with 290 60 woody species versus only 135 for non-Mediterranean Europe.

61 However, the characteristics of the Mediterranean area (longstanding anthropogenic pressure, significant current 62 human activity and broad biodiversity) make it one of the world's regions most threatened by current changes. 63 Four examples of Mediterranean forest types, present in south and north of the Mediterranean basin and more or 64 less threatened, are developed in order to show that linking "hard sciences" and humanities and social sciences is 65 necessary to understand these complex ecosystems. We show also that these forests, in spite of specific climatic 66 constraints, can also be healthy and productive, and play a major ecological and social role. Furthermore, even if 67 the current human activity and global change constitute a risk for these exceptional ecosystems, Mediterranean 68 forests represent a great asset and opportunities for the future of the Mediterranean basin.

70 Keywords: Mediterranean basin, forest, Quercus, Pinus, Juniperus, biodiversity, functioning, sustainability, 71 socio-ecological systems

72 Number of words contained in your manuscript text, including abstract, keywords and acknowledgements: 7081 


\section{Mediterranean forests, unique ecosystems?}

The founding paradigm of a specific "Mediterranean forest" appeared in forest science at the turn of the 19th and 20th century with two main objectives:

1. the scientific recognition of Mediterranean environmental specificity (soils, climate, vegetation) in northern-oriented forest science;

2. the legitimation of State intervention and mobilization of scientific knowledge for a "better" management of forest lands, commonly considered as heavily "degraded" by "anarchic and irrational" local agro-sylvo-pastoral practices (Auclair and Michon 2009).

The expansion of this founding paradigm (and of related forest laws and management models) was ensured in Europe by the establishment of "Silva Mediterranea" association in 1920, which allowed professionals from northern Mediterranean to promote their own models and references on the southern shore (Algeria, Tunisia, Morocco) by the French colonization, and the transfer of European forest regimes on Maghreb woodlands.

How can we then define a Mediterranean forest? The easiest way is to consider it as a forest that grows under Mediterranean climate, marked by a strong deficit of rainfall during the warm season, causing stress for the vegetation submitted to a dry summer period (Gauquelin 2011). We will restrict here to the forests of the Mediterranean basin which cover more than 48.2 million ha of which 35 million are in South Europe, 8.8 in Middle East and 4.4 in North Africa (adapted from Quézel and Médail 2003; Fady and Médail 2004).

It is however interesting to note that the European Environment Agency (EEA, 2006) does not consider an entity "Mediterranean forest" in his classification of European forests. Mediterranean forests can be found in three categories: thermophilous deciduous forests, broadleaved evergreen forests and coniferous forests.

\section{Climate and soils}

The seasonality in air temperature and precipitation, which is the most distinctive feature of the Mediterranean-type climates, has important implications on vegetation functioning, as it limits the active growing season to the humid period between fall and spring (Blondel and Aronson 1999). The length of this period ranges from 5 to 10 months according to distinct climatic subtypes.

In the Mediterranean basin, different parent rocks have given rise to very distinct soils and fertility levels, with siliceous rocks (part of Iberian Peninsula, Corsica, part of Provence), leading to strongly leached nutrient-poor soils in contrast to calcareous rocks leading to moderately leached and shallow high $\mathrm{pH}$ soils (Joffre and Rambal 2002; Joffre et al. 2008).

\section{We can also notice the:}

- Importance of erosion linked to the general sparse cover of soil by Mediterranean canopies and the high impact of human activity on soils and land use,

- low rate of organic matter in soils, mainly in arid environments,

- importance of rubification (or reddening) leading to the red color of some Mediterranean soils, 

microorganisms) involved in this key process, due to drought season.

\section{Structure and biological types}

As reported by EEA (2006), evergreen and sclerophyllous plants are mostly represented (though not exclusively) as deciduous forests, and particularly present in humid and perhumid bioclimates, showing the complexity of forests in the Mediterranean basin (Quézel and Médail 2003). In the Mediterranean region, the term "forest" not always referring to high, dense stands of trees with a closed canopy, three main forest types are distinguished (Quézel and Médail 2003) according to tree density and height but also presence of specific flora or soil type :

- Forests sensu stricto, with a specific sylvatic flora, growing on deep soils, mainly in areas less impacted by Human action and under the most favourable (sub-humid, humid, or more rarely semi-arid) bioclimates. These are cedar forests, deciduous or evergreen oak forests, and sometimes Tetraclinis forests.

- Pre-forestal structures, with lower trees density and height, found either in highly degraded areas, or in areas with less favourable climate (semi-arid or arid bioclimates), sometimes called matorrals.

- Pre-steppic structures with very low tree density and perennial steppic species in the understory. The climate is too cold or too dry to allow the development of a dense forest. High mountains forests like Juniperus thurifera stands (Gauquelin et al. 1999) or arid or pre-saharian stands with Vachellia tortilis subsp. raddiana, belong to this group. If we adopt FAO's definition (a forest should have more than $10 \%$ tree cover and trees higher than $7 \mathrm{~m}$ ), many of these pre-steppic formations can be considered as forests.

\section{Biodiversity}

Regarding biodiversity, the Mediterranean basin (sensu lato: 2\% of the Earth's surface) is one of 34 identified biodiversity hot spots based on the multitude of plant and animal species and the presence of a large number of endemic species (Médail and Quézel 1997; Benabid 2000). For instance, the region includes 25.000 flowering plants and ferns species (20\% of the world) which 50\% are endemics, with, among others, Tetraclinis articulata, Argania spinosa, Juniperus thurifera, Quercus suber or fir species as Abies pinsapo, Abies marocana, Abies nebrodensis, specific to each mountain of the Mediterranean (Blondel et al. 2010). The high plant diversity in the Mediterranean basin is primarily a result of a noteworthy diversity of habitats. For instance, in the Habitat Directive 92/43 of the European community, 117 out of the 199 habitats of community importance are occurring in this region and 93 of them are exclusively found there. The present Mediterranean flora is a complex mixture of taxa with very different biogeographic origins (Blondel et al. 2010):

- Afro tropical components, such Chamaerops or Argania,

- Holartic components, such Corylus,

- Irano Turanian components such Pistacia,

- Saharo Arabian components such Peganum,

- $\quad$ Indigenous and endemics. 
154 Concerning woody trees, the Mediterranean basin includes 290 woody species versus only 135 for non-

155 Mediterranean Europe. Fady (2005) showed that Mediterranean conifer species show higher diversity than other

156 conifers worldwide. The diversity is structured along a longitudinal gradient where eastern populations show

157 higher diversity than western populations, possibly as a result of increasing climate severity from east to west

158 during the Last Glacial Maximum, as well as re-colonization routes preferentially originating from eastern

159 refugia (Fady and Conord 2010). This trend is specific of the Mediterranean, whereas latitudinal spatial

160 structures are more often found in Europe (Petit et al. 2003), and is also observed across the tree of life,

161 particularly in insects (Conord et al. 2012). Other noticeable genetic diversity patterns in the Mediterranean

162 concern altitudinal clines, where low elevation species (particularly trees again) display less diversity than mid-

163 and high-elevation species (Conord et al. 2012). Finally, areas characterized as refugia and containing high

164 levels of genetic originality (private alleles, higher than average differentiation) are often found within regional

165 hotspots of plant diversity and endemism (Médail and Diadema 2009). And concerning birds, 343 breeding

166 species are present over an area three times lower than Europe (Blondel et al. 2010).

167 Soil mesofauna and microfauna, with numerous species and individuals occupying a wide range of ecological

168 niches, are other interesting representatives of biodiversity (De Nicola et al. 2014). In spite of the great interest

169 of these organisms, this compartment of biodiversity is still poorly understood in the Mediterranean forests.

170

\section{$171 \quad$ Functioning}

172 The specificity of Mediterranean forest ecosystems' functioning (phenology, primary and secondary

173 plant metabolism, carbon storage, productivity, water cycle, redistribution of nutrients and microorganisms

174 activity) is linked to the important drought period, with high discontinuity in functioning related to alternating

175 dry and wet periods.

176 In optimal conditions, the photosynthetic performance of Mediterranean species does not differ particularly from

177 that of species from other biomes. Nevertheless, their leaves have to tolerate high irradiance and they have to

178 cope with excess intercepted solar radiation when carbon assimilation is limited either by stomatal closure or a

179 decrease of photosynthetic capacity due to water stress and high temperatures or low temperatures (Joffre et al.

180 2008).

181 Mediterranean plant species produce numerous Plant Secondary Metabolites (PSMs), most of which are 182 terpenoids (volatiles) and phenolics (non volatiles). PSMs, together with morphological traits (sclerophylly),

183 allow these species to cope with climatic stress (Chaves and Escudero 1999). Their physiological role is still

184 under investigation, but numerous studies suggest their antioxidant role since they protect plants against UV as

185 well as heat and oxidative damage caused by episodes of pollution or drought (Yazaki 2006).

186 Plant investment in PSMs affects numerous processes in ecosystems functioning and biodiversity. For example,

187 leaf quality has direct effects on litter decomposition. These PSMs mediate also chemical interactions, via

188 allelopathic processes:

189 i. between plants since chemicals present phytotoxic effects irrespective of their functional group 190 (Bonanomi et al. 2006; Fernandez et al. 2013),

191 ii. between plants and microorganisms because PSMs inhibit soil microorganisms involved in nitrogen 192 cycling and forest regeneration (Pellissier et al. 2002; Jonsson et al. 2006; Chomel et al. 2014). 
PSMs are major determinants of community structure and ecosystem processes. For example, Pinus halepensis is rich in secondary metabolites (Pasqua et al. 2002; Macchioni et al. 2003; Fernandez et al. 2009) particularly terpenoids but also phenolics that are thought to play a role in plant-plant and plant-microorganisms interactions through allelopathic processes (Fernandez et al. 2006, 2008, 2009, 2013; Chomel et al. 2014). P. halepensis allelochemicals might drive plant biodiversity in Mediterranean, but their role in the variability of biodiversity has received little attention so far, particularly in stressful environments. Working on variations on $P$. halepensis PSMs (as functional leaf traits) along a stress gradient (drought), could enable us to understand biodiversity and biotic interactions in Mediterranean ecosystems but also the success of restoration operations.

\section{Litter decomposition and water stress}

Decomposition of organic matter, a key process for forest functioning, is controlled by biotic factors characteristics to the decomposers (bacteria, fungi, invertebrates), the biochemical composition of the plant litter (i.e. plant diversity; Santonja et al. 2015a) and the environmental conditions, particularly soil water content under Mediterranean climate. In summer, high temperature and low moisture, leading to persistent drought, can drastically limit microbial growth and activity (Criquet et al. 2004; Fioretto et al. 2005) whereas, the milder and wetter spring and autumn seasons induce higher metabolic rates of microbes temporarily enhancing the litter decomposition rates (Coûteaux et al. 1995). These markedly dry summer periods lead to a discontinuous decomposition process closely linked to water availability (Chomel et al. 2014).

\section{Mycorrhiza and water stress}

As stated earlier, Mediterranean forest ecosystems have a marked floristic diversity with an endemism level reaching 50\%. In this context, the question of the Mediterranean basin fungal diversity seems particularly relevant. Among fungi, diversity of mycorrhizal fungi present in these ecosystems is crucial as these symbiotic fungi are known as belowground linkers between plants, through hyphal networks, facilitating the access of their host plants to soil nutrients (Barto et al 2012). Additionally, mycorrhizal fungi considerably enhance their access to soil water compartment. Two main types of mycorrhizal fungi (ectomycorrhizal fungi or ECM, for woody

219 plants and arbuscular mycorrhizal ones or AM, for most plant species) are represented. The recent emergence of 220 new generation sequencing approaches permits to have a snapshot of soil fungal diversity in multiple and contrasted ecosystems all around the globe, including Mediterranean ones. This was the aim of a recent study by

222 Tedersoo et al (2014). These authors showed that all ecosystems host the main phylogenetic and functional groups of fungi, Agaricomycetes (non mycorrhizal fungi) being the dominant one in all situations. Regarding

224 Mediterranean biomes, their closer biomes in terms of ECM fungal diversities were grasslands and shrublands 225 and, to a less extent, tropical montane forests and tropical moist ones. One of their observations was that relative 226 ECM host plant density had a strong influence on ECM fungal richness, the highest ECM richness coinciding 227 with geographical distribution and dominance of Pinaceae, in the northern temperate biomes. Regarding 228 Glomeromycota (AM fungi), they have the lowest average geographical range, probably due to their relatively 229 big spores, not easily dispersed by the air.

230 As regards to global change, it is generally considered that ectomycorrhizal and AM communities respond 231 similarly to $\mathrm{CO}_{2}$ enrichment (Johnson et al. 2013). In both type of symbioses, $\mathrm{CO}_{2}$ enrichment has been shown 
to accelerate decomposition of soil organic matter, a phenomenon generally known as priming effect (Phillips et al. 2012).

\section{Spatial heterogeneity in Mediterranean forests}

We can evenly notice the influence of often wide spaced trees on biogeochemical cycles, soil characteristics and biodiversity (Joffre and Rambal, 1988; Gauquelin et al. 1992), leading to the very marked spatial heterogeneity, mainly in pre-forestal and pre-steppic stands. In peculiar man-made ecosystems characterized by a savannah-like physiognomy as dehesas and montados of the Iberian Peninsula, scattered trees imposed a marked spatial heterogeneity of ecosystem functioning. At the local scale, strong soil structural differences and functional differences in water budget and patterns of water use are observed under and outside the tree canopy. Using the concept of ecosystem mimicry, the two coexistent components of these agroforestry systems can be compared to two distant stages of a secondary succession, characterised by very different behaviours. At regional scale, evidence of relationships between tree density and mean annual precipitation suggests that the structure of these man-made agroecosystems dominated by evergreen oaks have adjusted over the long-term and correspond to an optimal functional equilibrium based on the hydrological equilibrium hypothesis (Joffre and Rambal 1993; Joffre et al. 1999).

\section{Dynamics}

Ecosystem dynamics are quite different on the southern and northern shores of the Mediterranean basin (Gauquelin 2011). The northern shore is characterized by coastal urbanization and an abandonment of agricultural and pastoral lands, leading to a spectacular forest re-colonization; for example, in the French Mediterranean area, forest (more than 1.4 million ha) increased between 0.5 and $2 \%$ by year between 1980 and 2011 (IF 2013; FAO 2013) which corresponds approximately to 16.000 ha by year. On the Southern shore, degradation is still intense and leads to fragmentation or disappearance of habitats including forest, with for example, an annually decrease rate of 0.5\% of the Algerian forest area from 1990 to 2010 (FAO 2013). But the situation can be contrasted. In Lebanon, as a result of unsustainable forest practices and neglect of forested lands, and as a result of the decline of controlled grazing in forest understory, oak and pine forests have become highly susceptible to fire events. Juniperus forests, a major element of the mountainous conifer forests in the eastern Mediterranean basin (Barbero et al. 1994), are negatively affected by the land exploitation. Continuous losses of the oldest individuals and a lack of regeneration could lead to a severe, genetically deleterious effect of fragmentation on local population diversity (Douaihy et al. 2011). In contrast, cedar forests have received national, regional and international attention due to their historic, symbolic and biological value (Sattout et al. 2005), even if they just constitute 1.58\% of the total forest cover (MOA/FAO, 2005). Massive reforestation programs are taking place in Lebanon today, taking advantage of the population genetic studies conducted on these emblematic species (Bou Dagher et al. 2007). 
Most of the forests in the Mediterranean region are the result of a long history of agro-sylvo-pastoral management by rural populations as well as of interactions between local societies and the State (mainly through the public Forest Administration) (Blondel 2006, Aubert 2013). In spite of this strong influence of local management practices and socio-political relationship on the production of Mediterranean forests, most scientific studies insist on the negative impact that local societies have had on "natural forests" and on their biodiversity (deforestation, forest degradation and desertification). Contrasting with these studies, Michon et al. (2007) have proposed to analyze the co-evolution between forest ecosystems and their related human populations in terms of domestication (of trees, ecosystems and landscapes), and to consider the resulting forests (domestic forests, or rural forests; Genin et al. 2013) as biocultural, or socio-ecological products for the agroforestry systems such as the ones of the Iberian Peninsula (Joffre et al. 1987, 1999).

Mediterranean forests have been in the past, and still are in certain region, intensively used for sustaining rural livelihoods. They provide a diversity of resources such as human food, medicines, ritual material, firewood, material wood and forage for livestock. These forests are characterized by different levels of formal and nonformal appropriation by rural communities and shaped by specific, refined knowledge and practices. They are also characterized by particular structures and functioning. Four major characteristics emerged from analyses in different contexts and form the identity of these domestic or rural forests (Genin et al. 2013):

1. specific forest structures and levels of integration in agricultural matrices, linked historically to overall agro-ecosystem structures and social practices (Genin and Simenel 2011),

2. a multiscale approach to domestication from individual trees up to landscape level, involving a continuity between "nature" (natural processes) and "culture" (human techniques of control and transformation), (Wiersum 1997, Michon 2015),

3. multiple uses of plants which vary in relation to the commercial or non-commercial status of their products and a reversible nature of these use patterns accordingly (Bahuguna 2000),

4. imbrications of different levels of access and control rules (between state and customary levels, between individual and collective levels), requiring specific formal and informal arrangements (Sandberg 2007). Rural forests are therefore social-ecological systems that contribute to ecosystem and landscapes configuration, definition of rural territories and sustainability of local livelihoods.

The counterproductive impact of public policies and forest science must be also pointed out (Michon et al. 2013). Most forestlands (and more particularly in the South) are State property and subject to forest laws. In the early $20^{\text {th }}$ century in northern Mediterranean, and until recently in the southern shore, issues related to the management of these State forests were specified in general terms, relying on representations developed in France in the late nineteenth century, that have always considered rural forests as "degraded forests" instead of specific systems of integrated rural forest management. For example, professional foresters seeing stands of highly pollarded trees frequently conclude to a generalized degradation of forests due to Human action, totally overlooking a specific management strategy aimed at enhancing forage production for livestock or pole production for roof construction. In order to "regenerate" these "degraded" forests, professional foresters largely rely on two strategies: 1/clear cuts and enclosures of "regenerating" stands in which all Human activity is banished and 2/ 
reforestation schemes with exotic tree species. Forests derived from such practices (stands of coppiced trees or exotic forests) are of poor interest for local people, who therefore often do not respect enclosures.

313 Recently, processes related to patrimonial construction at various scales in Mediterranean forests, have emerged 314 (such as the gazetting of the Moroccan argan forest as a biosphere reserve, or of the cedar forest as national 315 parks). These processes must be questioned: the ongoing patrimonial qualification of forests at national and 316 international levels for biological conservation or as elements of the world biocultural heritage could slowly 317 erasing local (rural) forest patrimonies and therefore, endangering the reproduction of these forests (Michon et al. 318 2012).

\section{Mediterranean forests and Climate change}

Climate models have predicted increases in both temperature and drought conditions in the Mediterranean (Giorgi and Lionello 2008, Somot et al. 2008). These changes are expected to result in increased frequency, intensity and duration of drought, especially during the warm season (Sheffield and Wood 2008; Podale et al. 2004). The response of Mediterranean forests to such extreme climatic events is poorly understood, because controlled field experiments to mimic such conditions are costly and difficult to operate on a large scale without introducing environmental modifications. Different in natura platforms have been implemented in different forest types in France, with rain exclusion devices allowing to apply a precipitation scenario close to what models predict for the end of the 21th century. Holm oak at Puechabon (Limousin et al. 2008, 2009, 2012), Aleppo pine at Font Blanche (Gea-Izquierdo et al. 2015) and downy oak at $\mathrm{O}_{3} \mathrm{HP}$ (Santonja et al. 2015b) are concerned. Results show that changing rainfall pattern will affect i) directly litter production and decomposition, ii) and volatile organic compounds emissions (Staudt et al. 2002, 2003; Genard et al. 2015). The idea is to develop around the Mediterranean basin a network of experimental stations with simpler and less expensive devices to monitor the effects of climate change in other important forest ecosystems and so under other bioclimates.

Concerning changes in forest vegetation over the last few decades, recent studies in northwestern Africa reported recurrent drought events from the second half of the 20th century (Touchan et al. 2010; Linares et al. 2011; Kherchouche et al. 2012, 2013; Slimani 2014). Touchan et al. (2008) showed that the 1999-2002 severe drought appears to be the worst in northwestern Africa since the middle of the 15th century. This suggests climate conditions more limiting to tree growth and drought-sensitive species geographical distribution, especially for those at the edge of their range. This event triggered substantial mortality in Cedrus atlantica forests where, in some areas, stands disappeared completely (Zine El Abidine 2003; Linares et al. 2011; Kherchouche et al. 2012, 2013; Slimani et al. 2014), and even in other tree species reputed for their drought hardiness, including Pinus halepensis, Quercus ilex, Quercus suber, and Juniperus thurifera (Allen et al. 2010).

\section{Four contrasting examples of relationships between functioning, structure and global change in Mediterranean forests}

Four examples illustrate relationships between human impacts, structure, dynamics and functioning of Mediterranean forests: Quercus pubescens (downy oak) forest, Quercus suber (cork oak) forest, Pinus 
halepensis (Aleppo pine) forest or Juniperus thurifera (thuriferous juniper) forest. They have a very different distribution (see maps in Quézel and Médail 2003) and they are respectively representative of the three tree functional types of the Mediterranean region: deciduous species malacophylles (specifically marcescent for downy oak) and evergreen sclerophyllous leaved and coniferous species (for cork oak, Aleppo pine and thuriferous juniper) (Table 1). They also have contrasting strategies to cope with drought and also very different dynamics according to past and current human impact, corresponding to different geographical trajectories (Table 1):

- France where abandonment of forest uses is the main feature and human pressure is very low (Southern Alps for juniper, Eastern Pyrenees for cork oak),

These comparative analyses are possible thanks to a long expertise of scientists who have been involved for many years in in-depth studies of local situations, with contrasted temporalities and organization in term of forest uses.

Forests of downy oak (Quercus pubescens): Which future for deciduous or marcescent oaks in the Mediterranean basin?

Spain where relictual uses and managements are still observed and human pressure is moderate to average (Northern Spain for thuriferous juniper, Andalucian dehesa for cork oak),

- Morocco, Algeria or Lebanon where forests are an important component for maintaining rural livelihoods and where human pressure is high, but with different modalities of governance in forest management (Agdal management system, a collectively-built management including seasonal rests and highly refined rules concerning multifunctional product extraction, for example, Auclair and Alifriqui, 2012), (High Atlas for thuriferous juniper, and Mamora forest for cork oak). coppicing practiced for centuries for charcoal production and are also used as rangeland
species does not exist in North Africa but is replaced by other related deciduous oak species.

384 The past, present and future place of deciduous oaks in the Mediterranean area (Pons and Quézel 1998) is 385 questioned, and the studies about impact of climate change on the functioning of these ecosystems must be 386 developed.

Quercus pubescens Willd. (downy oak) is a deciduous native oak widespread in southern Europe and southwest Asia, from northern Spain (Pyrenees) east to the Crimea and the Caucasus. It is also found in France (more than 1.000.000 ha) and parts of central Europe (Ganatsas et al. 2013). Moreover, the downy oak, often occurring in the transition of several climatic influences, seems to be especially responsive to climate change. The dramatic reduction of territories where marcescent oaks like downy oaks dominate, expected in the context of climate change in the near future in Spain (Sanchez de Dios et al. 2009), underlines the need of studies concerning this species, providing typical landscapes in the South of France. Forests generally result from coppicing practiced for centuries for charcoal production and are also used as rangeland for livestock. This

Forest of cork oak (Quercus suber): Which future for cork oak forests in relation to their economic value? 
for the past 3000 years, with an exploitation system combining ranching, agriculture and forestry. Cork oak ecosystems span from open savannas to closed forests. Bark is periodically harvested and represents the second most important marketable non-timber forest product in western Mediterranean. The cork oak ecosystems are also recognized for their remarkable ecological value, providing habitat for several threatened species and being protected by international legislation. But cork oak forests are threatened by wildfires, aging tree populations, abandonment in southwestern Europe and overuse in northwestern Africa where low regeneration rates are observed. Another threat is the recent decline of cork prices, due to the growing utilization of cork stopper substitutes. Cork oaks forests appear to be a good model to investigate about "Payment for Ecosystem Services" and economic incentives that promote ecological and economic viability of cork oak forests. It is also a good model to illustrate differences between Southern and Northern woodlands concerning threats and dynamics.

Forest of Aleppo pine (Pinus halepensis): Which future in the frame of global change?

The Aleppo pine is the most widespread pine in the Mediterranean basin (more than 3.5 million ha), mostly in the western Mediterranean. Since the early 19th century, the northern margins of the Mediterranean basin have undergone strong rural depopulation (Barbero et al. 1990; Debussche and Lepart 1992). Abandoned agricultural lands are soon to be naturally colonized by pioneer plant species through processes of secondary succession, with forest cover increasing fivefold over the last 150 years (Fernandez, Bousquet-Melou and Prevosto 2013). Among these pioneer species, Pinus halepensis Miller is considered as an expansionist species (Barbero and Quézel 1990) that presently dominates forests in this area (Acherar, Lepart and Debussche 1984; Debussche and Lepart 1992; Maestre and Cortina 2004), thereby, threatening the existing mosaic of forests, shrublands and pastures of high patrimonial value (Quézel and Médail 2003). The different stages of successional dynamics in these Mediterranean forest ecosystems dominated by Pinus halepensis are well described (Lepart and Escarré 1983; Quezel and Médail 2003), but the functional mechanisms determining these successional dynamics remain poorly understood. In the southern margins, where the main populations exist, dynamic and biodiversity of Aleppo pine forests are less known and should be compared to the northern populations.

Forest of thuriferous Juniper (Juniperus thurifera): Which dynamic North and South of the Mediterranean basin?

Thuriferous juniper is only found in isolated parts of western Mediterranean: France (Alps, Pyrenees and Corsican highlands), Spain, Algeria and Morocco with a total area more than 200.000 ha (Gauquelin et al. 2012; Gauquelin and Dutoit, 2013). These semi-arid mountain stands, where thuriferous juniper trees grow in low-density open woodland, are seriously endangered;

i. in the Atlas mountains, thuriferous juniper stands are heavily degraded as a result of intensive wood collection and livestock grazing (Gauquelin et al. 1999). This situation is in most parts, and could become irreversible by producing an impoverishment of soils and by leading to hillside instability. However, some still operating traditional practices concerning thuriferous juniper forests, can mitigate this degradation and promote some equilibriums between forest functioning and local population 

cultivation have strongly reduced areas occupied by Juniperus thurifera stands are still numerous and, in some regions, show a good regeneration due to conservation measures;

ii. in France, the decline in human and livestock activities over recent decades has led to a re-colonization of some of the Juniper stands by pines or oaks.

A forest management system that enables these original stands to survive and regenerate must be urgently undertaken. The dynamics of evolution of these stands is quite different north and south of the Mediterranean. In both cases, conservation measures (including positive protection measures designed locally by agro-silvopastoral societies) are urgently required to protect or rehabilitate the original stands with floristic, ecological and socio-economic interest. The idea is to better connect these different models, that are studied independently south and north of the Mediterranean, and to strengthen partnerships concerning Mediterranean forests researches. The comparison with the stands of Juniperus excelsa, a close species of thuriferous juniper developing in Lebanon, where human pressure is also strong, is very interesting.

Emphasis will be put, on the one hand, on the relationships between tree forms and architecture, and the functioning of the ecosystem, and, on the other hand, on the regeneration ability of tree stands submitted to diverse human impact degrees and management types. Hence, some traditional knowledge and local initiatives have led to construct other forms of forest management systems which have to be considered with new eyes by scholars. In the High Atlas for example, the agdal system, a collective management enterprise which always includes a period of rest in order to allow trees to recover from aerial exploitation (Hammi et al. 2010; Auclair and Alifriqui 2012), leads to differentially exploit forest patches, and creates a diversity of tree ports and forms whose functions participate, both, to secure livelihoods by providing differentiated resources (tree foliage, poles, beams) (Genin and Simenel 2011) and to diversified landscape biodiversity. Such resource use systems, far from being exclusively depredators for vegetation cover, could give interesting insights for renewing visions for socially and ecologically sound forest management approaches.

Examples found in these four forest models (e.g. dehesas, agdals, downy oak regeneration practices) give evidence that locally adapted forest management have long been developed by local societies in order to keep the capacity of forests to regenerate while providing goods and services on the long term. However, most of these practices are vanishing due to deep socio-economical, political, and livelihood transformations. This knowledge erosion is as alarming as the loss of biodiversity in Mediterranean forest, since it can be holder of innovative proposals for renewing our visions of what can make "a good forest management for the future".

Significant efforts are needed to globally understand, conserve and sustainably use these remarkable ecosystems.

\section{Conservation and sustainability use of Mediterranean forests} determines whether it is feasible to attempt to restore the original forest ecosystem or to just reforest the land again. 
In many countries, considerable research efforts are made to foster more reliable and precise reforestation when the natural regeneration is not sufficient or not possible, as the cost of reforestation is rising rapidly. Not only are labor, machines, and tree seed and seedling costs going up steeply, but the cost of borrowing money also has risen sharply in recent years. The ultimate target is to accomplish reforestation based on detailed physiological, ecological, and meteorological knowledge, inexpensively, quickly and reliably, and to ensure that trees grow rapidly after plantation.

474 One example concerns the resort to exotic trees, often been recommended in the past as a management option to enhance the productivity and biodiversity of Mediterranean disturbed ecosystems. Tree species such as Pinus spp., Eucalyptus spp. and Acacia spp. have been largely exported outside their natural range over the 18th and 19th centuries. Although these species are recommended to restore degraded ecosystems, it is now well established that they could threaten the structure and composition of plant cover and the vegetation dynamics (succession and dominance) and interact with the soil microbial community and modify mutualistic interactions within the native vegetation. Alteration of mycorrhizal community is of particular importance because it is considered as a key component of the sustainable soil-plant system (Hafidi et al. 2015). Performance of introduced species will be examined in relation to modifications of environmental factors (light availability, soil moisture and microclimatic conditions). Interactions between introduced seedlings, understorey and overstorey must be particularly studied to detect in which conditions competition or facilitation occur according to vegetation, species and site conditions (Duponnois et al. 2011).

Mediterranean forest ecosystems will have also to face significant disruptions of their functioning due to extreme climatic events, such as longer and more severe drought periods, increasing forest fire frequency and intensity and pest outbreaks (Moriondo et al. 2006; Lindner et al. 2010). These disturbances will put at risk a number of important ecosystems services (Schroter et al. 2005). In this context, new methods increasing the resistance and resilience of Mediterranean forests have to be developed, including those that harness the full potential of Mediterranean forest genetic resources (Lefèvre et al. 2014). For example, Pinus halepensis is particularly sensitive to current and future risks as this species is extremely flammable and can favour the spread of large forest fires (Pausas et al. 2008). This species can regenerate after a fire, thanks to a canopy-stored seed bank (Fernandes et al. 2011). But this strategy does not operate when fire intervals are shorter than the maturity age (Daskalakou and Thanos, 1996; Ne'eman et al. 2004). In addition, Aleppo pine forms mostly monospecific stands that are highly sensitive to insect attacks (Maestre and Cortina 2004). Mixed stands, e.g. combining pine and hardwood species, are expected to be less sensitive to pest outbreaks and herbivory (Jactel et al. 2006; Jactel and Brockerhoff 2007), to host a higher biodiversity and to be more resilient to disturbances and changing environmental conditions for a number of ecosystem processes (Yachi and Loreau 1999). Favouring mixed pinehardwood species stands is therefore a strategy increasingly put forward in order to enhance forest resilience

502 (Pausas et al. 2004).

503 The impact of different vegetation conditions (including different canopy covers, presence or not of shrubby 504 vegetation) on the response of introduced hardwood of various species differing in various ecological traits 505 (ability to withstand shade and water stress in particular), must be tested in different contrasted Mediterranean 
between the different strata (regeneration/understorey/overtsorey) in relation to the use of the main resources (water, light) must be proposed.

6. Conclusion: conciliating particular ecological functioning, biocultural heritage and threats

A linkage between different elements allows proposing an integrative and original outlook of Mediterranean forests:

- Linking fundamental and applied research: all scientific results should allow implementing a successful strategy for the preservation and development of Mediterranean forests. Knowledge of the different biodiversity levels could help preserve Mediterranean forests. At the species level, the genetic diversity studies and the adaptive potential of the species could help understand its reactions to environment change. At the community level, understanding interactions between different species could have drastic changes on reforestation practices. For instance, identifying the mycorhizal community of some trees used in reforestation programs and the nurse effect of some shrub species on these trees could bring high hope for large scale reforestation programs, reducing watering cost and rising success rate of these plantations. On the other hand, climate modelling applied to species distribution and genetic exploration of marginal populations can also help predict species range shifts and lighten conservation actions.

- Linking "hard sciences" and humanities and social sciences: in the Mediterranean forests, the understanding of these ecosystems and their future must first integrate 1) the secular human-forest interactions which have shaped functional cultural landscapes, and 2) the ecosystem services provided by these forests for securing both overall diverse ecosystems and livelihoods.

- Linking academic knowledge and traditional knowledge: we have seen that some localized practices, such as the Agdal system for example, give attention to both forest protection and exploitation for local livelihood improvement. There is therefore an urgent need to better survey and understand the ways local population perceive and manage their forest resources, in order to facilitate hybridization of knowledge for integrated proposals that make sense to both parts, and could effectively be applied and respected.

- Linking forestry, agricultural and social approaches and objectives: forests and human populations living in and from these forests have to be protected in a global, comprehensive approach taking into account biological and cultural diversity, which requires truly participative methods (i.e. not forcing local population to participate in projects designed by foresters or biologists who aim at preserving forests per se, but developing negotiation processes in which all stakeholders have to be heard).

- $\quad$ Linking North and South of the Mediterranean: forest structure, dynamics and threats are very different on the two shores of the Mediterranean and confrontation between these different situations is essential to understand the global evolution of Mediterranean forests. For example, are Aleppo pine, cork oak or thuriferous Juniper forests the same South or North according to their structure, functioning, utilization, biodiversity or vulnerability? Which relationships between Aleppo pine and the two oaks in the North? 
- Linking biodiversity, evolution, dynamics and functioning in these forests in order to put in evidence the need to preserve this biodiversity.

- Linking "nature" and productive systems: this aspect, and particularly in the Mediterranean basin, shows a continuum between "wild" and highly anthropized ecosystems, which has to be better understood in order to detect forms of uses enable to guarantee both sustainability of these sensitive forest ecosystems and local livelihoods.

553 Mentioning the necessity of these linkages may appear incantatory as it barely refers to actually occurring 554 dynamics. It is also difficult to report true "success stories" in developing productive "biocultural" approaches, 555 i.e. in combining ecological and cultural approaches for a better understanding and management of 556 Mediterranean forests, as these two approaches are generally badly connected. However, some examples of what should not occur and some ideas of what could be achieved can be derived from researches conducted by various disciplines on the argan forest of Morocco. Biologists consider this forest as a unique forest (with the endemic argan tree and associated forest flora, and ecological services it provides). They also consider this forest as highly threatened by local agro-silvo-pastoral practices hampering the regeneration of the argan tree and reducing floristic diversity (Michon et al. 2016). Social sciences consider the argan forest as a unique example of socio-ecological system linking biological and cultural diversity for the management and reproduction of both a fragile forest ecosystem in arid conditions and a productive agroforestry system (M'Hirit et al. 1998). Combined

564 ecological and cultural approaches highlight the ambiguity of "degradation narratives" in the argan forest (El 565 Wahidi et al. 2014). In areas where human out-migration is occurring (the Anti-Atlas mountains), dense forest 566 vegetation is quickly developing. But as terraces are abandoned, soil erosion is accelerating (which, in the 567 context or increasing extreme rainfall episodes, can become a problem), and bushy undergrowth vegetation is 568 developing, which increases risks of forest fires. Moreover, the argan socio-ecological system is degrading, with 569 the erosion of local knowledge and practices. The "biological forest" is regenerating, the "cultural forest" is vanishing. Foresters, biologists, local populations and social scientists could join their efforts in order to define what is a desirable "state of conservation" for this rural forest, taking into account flora, fauna, ecological services as well as local knowledge, practices and productions. Practical measures to reach, monitor and maintain this state have to be invented mobilizing scientific as well as local indicators of "degradation", regeneration practices, protection measures (for example combining the protective enclosure methods of foresters and the agdal practices of local populations). This can be done only if local populations are integrated from the very beginning in the definition of conservation management objectives. The same global model can be mentioned for the cork oak forest, a formerly "cultural forest" in the northern part of the Mediterranean basin, "naturalized" since local practices of cork oak management have been abandoned, and presently heavily impacted by fires. Conservation of the cork-oak forest may go through reactivating the interest of local farmers into global ecosystem management for combined cork, pastoral and agricultural productions. Such management models still exist in Spain and south of the Mediterranean basin that could inspire the rehabilitation of 582 abandoned cork oak forests in the North.

583 This synthesis should highlight both the risks of Mediterranean forest ecosystems and their potential, as well as 584 the opportunities they represent for sustainable development integrating the "man" and its activities. The idea is 
585 to project in 2100 by integrating global change (including climate change, land use change, socio-economic, 586 etc...) and make proposals in this direction. Dialogue and meeting between the actors of this project will be the 587 main tool to succeed in this challenge. 
We dedicate this paper to the memory of Pierre Quézel, who played a key role in the knowledge of Mediterranean forests. The authors gratefully acknowledge the program MISTRALS (Mediterranean Integrated STudies at Regional And Local Scales), particularly the axes SICMED and BIODIVMEX, and also the program

ENVIMED. Finally, we are grateful to two reviewers and the guest editor for valuable comments.

593

594

595

596

597

598

599

600

601

602

603

604

605

606

607

608

609

610

611

612

613

614

615

616

617

618

619

620

621

622

623

624

625

626

\section{References}

Acherar M, Lepart J, Debussche M (1984) La colonisation des friches par le pin d'Alep (Pinus halepensis) en Languedoc méditerranéen. Acta oecologica. Oecologia plantarum 5: 179-189

CD, Macalady AK, Chenchouni H, Bachelet D, McDowell N, Vennetier M, Kizberger T, Rigling A, Breshears DD, Hogg EH, Gonzalez P, Fensham R, Zhang Z, Castro J, Demidova N, Lim JH, Allard G, Running SW, Semerci A, and Cobb N (2010) A global overview of drought and heat-induced tree mortality reveals emerging climate change risks for forests. Forest Ecology and Management 259: 660-684

Aubert PM (2013) Les évolutions de la politique forestière au Maroc : entre réappropriation du modèle forestier français e et idéalisation de la tribu. Rev. For. Fr. LXV- 4-2013 : 305-316

Auclair L, Michon G (2009) La forêt rurale méditerranéenne entre deux paradigmes-étude comparée des constructions patrimoniales de l'arganeraie marocaine et de la châtaigneraie corse. Forêt Méditerranéenne 30(2):123-133

Auclair L, Alifriqui M (Eds) (2012) Agdal : Patrimoine socio-écologique de l'Atlas marocain. IRCAM-IRD, Rabat, Maroc, $546 \mathrm{p}$

Bahuguna VK (2000) Forests in the economy of the rural poor: an estimation of the dependency level. Ambio 29:126-129

Barbero M, Bonin G, Loisel R, Quézel P (1990) Changes and disturbances of forest ecosystems caused by human activities in the western part of the Mediterranean basin. Vegetatio 87: 151- 173

Barbero M, Lebreton $\mathrm{Ph}$ and Quezel P (1994) Sur les affinités biosystématiques et phytoécologiques de Juniperus thurifera L. et de Juniperus excelsa Bieb. Ecologia Mediterranea 20(3/4): 21-37

Barbero M, Quézel P (1990) La déprise rurale et ses effets sur les superficies forestières dans la région ProvenceAlpes-Côte d'Azur. Bull. Soc. linn. Provence 41: 77-88.

Barto EK, Weidenhamer JD, Cipollini D, Rillig MC (2012) Fungal superhighways: do common mycorrhizal networks enhance below ground communication? Trends in Plant Science 17:633-637

Benabid A (2000) Flore et écosystèmes du Maroc. Evaluation et préservation de la biodiversité. Ibis Press, Paris $360 \mathrm{p}$.

Blondel J (2006) The “design” of Mediterranean landscapes: a millennial story of human and ecological systems during the historic period. Human Ecology 34:713-730. http://dx.doi.org/10.1007/s10745-006-9030-4

Blondel J, Aronson J (1999) Biology and Wildlife of the Mediterranean Region. Oxford University Press.

Blondel J, Aronson J, Bodiou JY, Boeuf G (2010) The Mediterranean Region: Biological Diversity in Space and Time. Oxford University Press. 
Bonanomi G, Sicurezza MG, Caporaso S, Esposito A, Mazzoleni S (2006) Phytotoxicity dynamics of decaying plant materials. New Phytologist 169(3): 571-578

Bou Dagher-Kharrat M, Mariette S, Lefèvre F, Grenier G, Plomion C, Savouré A (2007) Geographical diversity and genetic relationships among Cedrus species estimated by AFLP. Tree Genetics \& Genomes 3: 275-285

Chaves N, Escudero JC (1999) Variation of flavonoid synthesis induced by ecological factors. In : Principles and practices in plant ecology: Allelochemical interaction, Inderjit, Dakshini K. M. M. and Foy C. L. edit., CRC Press publ., 267-285

Chomel M, Fernandez C, Bousquet-Mélou A, Monnier Y, Santonja M, Gauquelin T, Gros R, Lecareux C, Dupouyet S, Baldy V (2014) Secondary metabolites of Pinus halepensis alter decomposer organisms and litter decomposition during afforestation of abandoned agricultural zones. Journal of Ecology 102 (2): 411-424

Conord C, Gurevich J, Fady B (2012) Large-scale longitudinal gradients of genetic diversity: a meta-analysis across six phyla in the Mediterranean basin. Ecology \& Evolution 2(10):2595-2609

Coûteaux MM, Bottner P, Berg B (1995) Litter decomposition, climate and litter quality. Tree 10:63-66

Criquet S, Ferre E, Farnet AM, Le Petit J (2004) Annual dynamics of phosphatase activities in an evergreen oak litter: influence of biotic and abiotic factors. Soil Biol Biochem 36:1111-1118

Daskalakou E, Thanos C (1996) Aleppo Pine (Pinus halepensis) postfire regeneration: the role of canopy and soil seed banks. International Journal of Wildland Fire 6:59-66

Debussche M, Lepart J (1992) Establishment of woody-plants in Mediterranean old fields - opportunity in space and time. Landscape Ecology 6:133-145.

De Nicola C, Zanella A, Testi A, Fanelli G, Pignatti S (2014) Humus forms in a Mediterranean area (Castelporziano Reserve, Rome, Italy): classification, functioning and organic carbon storage. Geoderma 235-236: 90-99. doi: 10.1016/j.geoderma.2014.06.033

Douaihy B, Vendramin GG, Boratynski A, Machon N, Bou Dagher-Kharrat M (2011) High genetic diversity with moderate differentiation in Juniperus excelsa from Lebanon and the eastern Mediterranean region. AoB Plants vol 0.

Duponnois R, Ouahmane L, Kane A, Thioulouse J, Hafidi M, Boumezzough A, Prin Y, Baudoin E, Galiana A, Dreyfus B (2011) Nurse shrubs increased the early growth of Cupressus seedlings by enhancing belowground mutualism and soil microbial activity, Soil Biology and Biochemistry 43: 2160-2168

EEA (2006) European forest types categories and types for sustainable forest management. reporting and policy. Technical report $113 \mathrm{p}$

Fady B, Conord C (2010) Macroecological patterns of species and genetic diversity in vascular plants of the Mediterranean Basin. Diversity \& Distributions 16(1):53-64

Fady B, Médail F (2004) Mediterranean Forest Ecosystems. In: J. Burley, J. Evans and J.A. Youngquist edit., 
FAO (2010). Global forest resources assessment 2010. Main report. FAO Forestry Paper No. 163 Rome.

FAO (2013) State of Mediterranean Forests. pp. 1-177. Rome.

669 Fernandes PM, Rego FC, Rigolot E (2011) The FIRE PARADOX project: Towards science-based fire management in Europe. Forest ecology and management 261:2177-2178..doi: 10.1016/j.foreco.2010.12.024)

Fernandez C, Bousquet-Mélou A, Prévosto B (2013) Répartition dans le bassin méditerranéen et en France. Le pin d'Alep en France (ed. B. Prévosto), pp. 23-27. Editions Quæ, Versailles

Fernandez C, Lelong B, Vila B, Mévy JP, Robles C, Greff S, Dupouyet S, Bousquet-Mélou A (2006) Potential allelopathic effect of Pinus halepensis in the secondary succession: an experimental approach. Chemoecology 16:97-105

Fernandez C, Santonja M, Gros R, Monnier Y, Chomel M, Baldy V, Bousquet-Mélou A (2013) Allelochemicals of Pinus halepensis as drivers of biodiversity in Mediterranean open mosaic habitats during the colonization stage of secondary succession. J Chem Ecol 39 (2):298-311

Fernandez C, Voiriot S, Mevy JP, Vila B, Ormeño E, Dupouyet S, Bousquet-Melou A (2008) Regeneration failure of Pinus halepensis Mill.: The role of autotoxicity and some abiotic environmental parameters. Forest Ecol Manag 255:2928-2936

Fernandez, C, Monnier, Y, Ormeño E, Baldy V, Greff, S, Pasqualini, V, Mévy, JP, And Bousquet-Melou, A (2009) Variations in allelochemical composition of leachates of different organs and maturity stages of Pinus halepensis. J Chem Ecol 35:970-979

Fioretto A, Di Nardo C, Papa S, Fuggi A (2005) Lignin and cellulose degradation and nitrogen dynamics during decomposition of three leaf litter species in a Mediterranean ecosystem. Soil Biol Biochem 37:10831091

Ganatsas P, Tsakaldimi M (2013) A comparative study of desiccation responses of seeds of three droughtresistant Mediterranean oaks. Forest ecology and management 305: 189-194

Gauquelin T (2011) Specificity and universality of Forestal Mediterranean ecosystems. In : Hafidi Mohamed (ed.), Duponnois Robin (ed.). The mycorrhizal symbiosis in Mediterranean environment : importance in ecosystem stability and in soil rehabilitation strategies. New York : Nova Science Publishers, :1-5

Gauquelin T, Bertaudiere V, Montes N, Badri W, Asmode JF (1999) Endangered stands of thuriferous juniper in the western Mediterranean basin. Biodiversity and Conservation 8:1479-1498

Gauquelin T, Chondroyannis P, Boukhdoud N, Bouyssou M, Brunel C, Danneyrolles V, Delforge Q, Guiraud M, Marchand C, Mathaux C, Orighoni H, Quent M, Sbeiti A, Sinet R (2012) Le Genévrier thurifère, espèce partagée au Nord et au Sud de la Méditerranée Exemple d'une approche d'écologie globale à l'occasion du IVe colloque international de Saint-Crépin et Mont-Dauphin (5-8 octobre 2011) Forêt méditerranéenne 33: 227-240

Gauquelin T, Dutoit T (2013) Actes du IVe colloque international sur le Genévrier thurifère 5-8 octobre 2011.Numéro spécial Ecologia Mediterranea 39 (1) 218p.

Gauquelin T, Fromard F, Badri W, Dagnac J (1992) Apports d'éléments minéraux au sol par l'intermédiaire de la litière, des pluies et des pluviolessivats dans un peuplement à genévrier thurifère (Juniperus thurifera L.) du Haut Atlas occidental (Maroc). Annales des Sciences Forestières 49:599-614

Genard AC, Boissard C, Fernandez C, Kalokridis C, Gros V, Lathière J, Bonnaire N, Ormeño E (2015) BVOC 
(isoprene) emissions from a Mediterranean Quercus pubescens and Acer monspessulanum canopy under mild drought. Atmos Chem Phys 15:431-446

Genin D, Aumeerudy-Thomas Y, Balent G, Nasi R (2013) The multiple dimensions of rural forests: lessons from a comparative analysis. Ecology and Society 18(1):27

Gea-Izquierdo G, Guibal F, Joffre R, Ourcival JM, Simioni G, Guiot J (2015) Modelling the climatic drivers determining photosynthesis and carbon allocation in evergreen Mediterranean forests using multiproxy long time series Biogeosciences 12 (12) : 3695-3712 DOI: 10.5194/bg-12-3695-2015

Genin D, Kerautret L, Hammi S, Cordier J.B, Alifriqui M (2012) Biodiversité et pratiques d'agdal. Un élément

Genin D, Simenel R (2011) Endogenous Berber management and the shaping of rural forests in Southern Morocco: implications for shared forest management options. Human Ecology 39:257-269

Joffre R, Vacher J, De Los Llanos C, Long G (1987) The dehesa : an agrosilvopastoral system of the

Giorgi F, Lionello P (2008) Climate change projections for the Mediterranean region. Gl \& Planetary Change 63(2-3):90-104, doi: 10.1016/j.gloplacha.2007.09.005

Hafidi M, Qaddoury A, Duponnois R, Wipf D, Hijri M, Bâ A (2015) International Congress on Mycorrhizae: mycorrhizal symbiosis a key factor for improving plant productivity and ecosystems restoration. Mycorrhiza 25:673-674. DOI 10.1007/s00572-015-0637-4

Hammi S, Simonneaux V, Cordier JB, Genin D, Alifriqui M, Montes N, Auclair L (2010) Can traditional forest management buffer forest depletion? Dynamics of Moroccan High Atlas Mountain forests using remote sensing and vegetation analysis. Forest Ecology and Management, 260(10): 1861-1872

IF, Le supplement d'IGN Magazine sur l'information forestière (2013) Un siècle expansion des forêts françaises. Numéro $31,8 \mathrm{p}$.

Jactel H, Brockerhoff EG (2007) Tree diversity reduces herbivory by forest insects. Ecology Letters 10: 835-848

Jactel H, Menassieu P, Vétillard F, Gaulier A, Samalens JC, Brockerhoff EG (2006) Tree species diversity reduces the invasibility of maritime pine stands by the bast scale, Matsucoccus feytaudi (Homoptera: Margarodidae). Can. J. For. Res. 36 : 314-323

Joffre R, Rambal S (1988) Soil water improvement by trees in the rangelands of southern Spain. Acta Oecologica, 9 (4): 405-422

Joffre R, Rambal S (1993) How tree cover influences the water balance of Mediterranean rangelands. Ecology 74: $570-582$

Joffre R, Rambal S (2002) Mediterranean ecosystems. In Encyclopedia of Life Sciences, (Nature Publishing Group, ed.), www.els.net 14 p. Macmillan Publishers Ltd, London.

Joffre R, Rambal S, Damesin C (2008) Functional attributes in Mediterranean-type ecosystems. In Handbook of functional plant ecology $2^{\text {nd }}$ ed. (eds FI Pugnaire \& F Valladares), CRC Press Books, Boca Raton

Joffre R, Rambal S, Ratte JP (1999) The dehesa system of southern Spain and Portugal as a natural ecosystem mimic. Agroforestry Systems 45: 57-79 Mediterranean region with special reference to the Sierra Morena area of Spain. Agroforestry Systems 6:71-96. 
Johnson NC, Angelard C, Sanders IR, Kiers ET (2013) Predicting community and ecosystem outcomes of mycorrhizal responses to global change. Ecology Letters 16: 140-153

Jonsson, LM, Dighton J, Lussenhop J, Koide RT (2006) The effect of mixing ground leaf litters to soil on the development of pitch pine ectomycorrhizal and soil arthropod communities in natural soil microcosm systems. Soil Biol \& Bioch 38(1): 134-144

Kherchouche D, Kalla M, Gutierrez E, Briki A, Hamachi A (2013) La sécheresse et le dépérissement du cèdre de l'Atlas (Cedrus atlantica Manetti) dans le massif du Belezma (Algérie). Sécheresse 24 (2) : 129-137

Kherchouche D, Kalla M, Gutiérrez EM, Attalah S, Bouzghaia M (2012) Impact of droughts on Cedrus atlantica forests dieback in the Aurès (Algeria). Journal of Life Sciences $6: 1262-1269$

Lefèvre F, Boivin T, Bontemps A, Courbet F, Davi H, Durand-Gillmann M, Fady B, Gauzere J, Gidoin C, Karam M-J, Lalagüe H, Oddou-Muratorio S, Pichot C (2014) Considering evolutionary processes in adaptive forestry. Annals of Forest Science 71: 723-739

Lepart J, Escarré J (1983) La succession végétale, mécanismes et modèles : analyse bibliographique. Bulletin d'écologie 14 : 133-178

Limousin JM, Rambal S, Ourcival JM, Joffre R (2008) Modelling rainfall interception in a Mediterranean Quercus ilex ecosystem: lesson from a throughfall exclusion experiment. Journal of Hydrology 357: 57-66

Limousin JM, Rambal S, Ourcival JM, Rocheteau A, Joffre R, Rodriguez-Cortina R (2009) Long-term transpiration change with rainfall decline in a Mediterranean Quercus ilex forest. Global Change Biology 15:2163-2175

Limousin JM, Rambal S, Ourcival JM, Rodríguez-Calcerrada J, Pérez-Ramos I, Rodríguez-Cortina R, Misson L, Joffre R (2012) Morphological and phenological shoot plasticity in a Mediterranean evergreen oak facing long-term increased drought. Oecologia 169:565-577

Linares JC, Taïqui L, Camarero JL (2011) Increasing drought sensitivity and decline of Atlas cedar (Cedrus atlantica) in the Moroccan Middle Atlas forests, Forests 2 (3), 777-796, doi: 10.3390/f2030777

Lindner M, Maroschek M, Netherer S, Kremer A, Barbati A, Garcia-Gonzalo J, Seidl R, Delzon S, Corona P, Kolström M, Lexer MJ, Marchetti M (2010) Climate change impacts, adaptive capacity, and vulnerability of European forest ecosystems. Forest Ecology and Management 259: 698-709

Macchioni F, Cioni PL, Flamini G, Morelli I, Maccioni S, Ansaldi M (2003) Chemical composition of essential oils from needles, branches and cones of Pinus pinea, P. halepensis, P. pinaster and P. nigra from central Italy. Flavour and Fragance Journal 18:139-143

Maestre FT, Cortina J (2004) Are Pinus halepensis plantations useful as a restoration tool in semiarid Mediterranean areas? Forest Ecology and Management 198: 303-317

Médail F, Quézel P (1997) Hot-Spots Analysis for Conservation of Plant Biodiversity in the Mediterranean Basin. Annals of the Missouri Botanical Garden 84 : 112-127

Médail F, Diadema K (2009) Glacial refugia influence plant diversity patterns in the Mediterranean Basin. Journal of Biogeography 36:1333-1345

M'hirit O, Benzyane M, Benchekroun F, El Yousfi S M, Bendaanoun M (1998) L'arganier, une espèce fruitièreforestière à usages multiples, Mardaga, Sprimont, Belgique, Belgique, 145 p.

Michon G (2015) Agriculteurs à l'ombre des forêts du monde. Arles, Actes Sud, 251p. 
Michon G, de Foresta H, Levang P, Verdeaux F (2007) Domestic forests: a new paradigm for integrating local communities' forestry into tropical forest science. Ecology and Society 12(2):1

Michon G, Nasi R, Balent G (2013) Public policies and management of rural forests: lasting alliance or fool's dialogue? Ecology and Society 2013 18(1):30

Michon G, Romagny B, Auclair L, Deconchat M (2012) Forests as patrimonies? From theory to tangible processes at various scales. Ecology and Society 17(3):7

Pons A, Quézel P (1998) A propos de la mise en place du climat méditerranéen. CR Acad Sci Paris 327: 755760

Quézel P, Médail F (2003) Ecologie et biogéographie des forêts du bassin méditerranéen. Elsevier, Paris 573 p. 
Sandberg A (2007) Property rights and ecosystem properties. Land Use Policy 24:613-623

Santonja M, Baldy V, Fernandez C, Balesdent J, Gauquelin T, Baldy V (2015a) Potential shift in plant communities with climate change: outcome on litter decomposition and nutrient release in a Mediterranean oak forest. Ecosystems 18: 1253-1268

Santonja M, Fernandez C, Gauquelin T, Baldy V (2015b) Climate change effects on litter decomposition: intensive drought leads to a strong decrease of litter mixture interactions. Plant and Soil 393: 69-82

Sattout E, Talhouk S, Kabbani N (2005). Lebanon. In M. Merlo \& L. Croitoru(Ed.), Valuing Mediterranean Forests : Towards Total Economic Value (pp. 397). Oxfordshire, UK: CABI Publishing

Schroter D, Cramer W, Leemans R, Prentice IC, Araujo MB, Arnell NW, Bondeau A, Bugmann H, Carter TR, Gracia CA, de la Vega-Leinert AC, Erhard M, Ewert F, Glendining M, House JI, Kankaanpää S, Klein RJ, Lavorel S, Lindner M, Metzger MJ, Meyer J, Mitchell TD, Reginster I, Rounsevell M, Sabaté S, Sitch S, Smith B, Smith J, Smith P, Sykes MT, Thonicke K, Thuiller W, Tuck G, Zaehle S, Zierl B (2005) Ecosystem service supply and vulnerability to global change in Europe. Science 310: 1333-1337

Sheffield J, Wood EF (2008) Projected changes in drought occurrence under future global warming from multimodel, multi-scenario, IPCC AR4 simulations. Climate Dynamics 31(1):79-105, doi: 10.1007/s00382007-0340-z

Slimani S (2014) Reconstitutions dendrochronologiques du climat et de l'historique des incendies dans les régions des Aurès et de Kabylie, nord de l'Algérie. Doctoral Thesis. The University Mouloud Mammeri, Tizi Ouzou, Algeria. $171 \mathrm{p}$

Slimani S, Derridj A, Gutiérrez E (2014) Ecological response of Cedrus atlantica to climate variability in the Massif of Guetiane (Algeria). Forest Systems 23 (3) : 448-460. http://dx.doi.org/10.5424/fs/201423305175

Somot S, Sevault F, Déqué M, Crépon M (2008) 21st century climate change scenario for the Mediterranean using a coupled atmosphere-ocean regional climate model. Global Planet Change 63(2-3):112-126, doi: 10.1016/j.gloplacha.2007.10.003

Staudt M, Joffre R, Rambal S (2003) How growth conditions affect the capacity of Quercus ilex leaves to emit monoterpenes New Phytologist 158: 61-73

Staudt M, Rambal S, Joffre R (2002) Impact of drought on seasonal monoterpene emissions from Quercus ilex in southern France. Journal of Geophysical Research, 107, D21. Art n 4602

Tedersoo L, Bahram M, Põlme S, Kõljalg U, Yorou NS, Wijesundera R, Villarreal Ruiz L, Vasco-Palacios AM, Quang Thu P, Suija A, Smith, ME, Sharp C, Saluveer E, Saitta A, Ratkowsky D, Pritsch K, Riit T, Põldmaa K, Piepenbring M, Phosri C, Peterson M, Parts K, Pärtel K, Otsing E, Nouhra E, Njouonkou AL, Nilsson RH, Morgado LN, Mayor J, May TW, Kohout P, Hosaka K, Hiiesalu I, Henkel TW, Harend H, Guo L, Greslebin A, Grelet G, Geml J, Gates G, Dunstan W, Dunk C, Drenkhan R, Dearnaley J, De Kesel A, Dang T, Chen X, Buegger F, Brearley FQ, Bonito G, Anslan S, Abell S, Abarenkov K (2014) Global diversity and geography of soil fungi. Science 346: 1256688

Touchan R, Anchukaitis KJ, Meko DM, Attalah S, Baisan C, Aloui A (2008) Long term context for recent drought in northwestern Africa. Geophysical Research Letters 35, L13705. doi:10.1029/2008GL034264. 
Touchan R, Anchukaitis KJ, Meko DM, Sabir M, Attalah S, Aloui A (2010) Spatiotemporal drought variability in northwestern Africa over the last nine centuries. J. Clim. Dynam. 37: 237-252, doi:10.1007/s00382-010-0804-4

Wiersum KF (1997) Indigenous exploitation and management of tropical forest resources: an evolutionary continuum in forest-people interactions. Agriculture, Ecosystems and Environment 63:1-16.

872 Yachi S, Loreau M (1999) Biodiversity and ecosystem productivity in a fluctuating environment: The insurance hypothesis. Proceedings of the National Academy of Sciences of the United States of America, 96: $1463-1468$

Yazaki K (2006) ABC transporters involved in the transport of plant secondary metabolites. FEBS Letters 580(4): 1183-1191

Zine El Abidine AZ (2003) Forest decline in Morocco: causes and control strategy. Science et changements

879 planétaires. Sécheresse 14: 209-218 
Table 1: Comparative data on biological type, bioclimatic stage, distribution area and dynamics, main uses, ecosystems

882 services, human pressure and threats for the four studied species. Sources of data : Pons and Quezel 1998; Quézel and Médail

883 2003; Fernandez, Bousquet-Melou and Prevosto 2013; Gauquelin et al. 1999.

\begin{tabular}{|c|c|c|c|c|c|c|}
\hline Species & $\begin{array}{c}\text { Biological } \\
\text { type }\end{array}$ & Bioclimatic stage & $\begin{array}{c}\text { Distribution } \\
\text { area } \\
\text { Dynamics } \\
\end{array}$ & Main uses & $\begin{array}{l}\text { Ecosystems } \\
\text { services }\end{array}$ & $\begin{array}{c}\text { Human pressure } \\
\text { and threats }\end{array}$ \\
\hline $\begin{array}{l}\text { Quercus } \\
\text { pubescens } \\
\text { Downy } \\
\text { Oak }\end{array}$ & $\begin{array}{l}\text { Deciduous, } \\
\text { marcescent }\end{array}$ & $\begin{array}{l}\text { Submediterraaneaan } \\
\text { and mediterranean } \\
\text { (mesomediterranean } \\
\text { and } \\
\text { supramediterranean) }\end{array}$ & $\begin{array}{c}\text { Widely } \\
\text { distributed } \\
>2 \text { million ha } \\
\text { Extension }\end{array}$ & $\begin{array}{l}\text { Wood for fuel } \\
\text { and charcoal }\end{array}$ & $\begin{array}{c}\text { Regulation } \\
\text { Provisioning } \\
\text { Habitat } \\
\text { Cultural }\end{array}$ & $\begin{array}{c}\text { Low } \\
\text { Climate change }\end{array}$ \\
\hline $\begin{array}{l}\text { Quercus } \\
\text { suber } \\
\text { Cork Oak }\end{array}$ & evergreen & $\begin{array}{l}\text { Western part of the } \\
\text { Mediterranean } \\
\text { (thermomediterranean } \\
\text { and } \\
\text { mesomediterranean) } \\
\text { and atlantic }\end{array}$ & $\begin{array}{c}\text { Widely } \\
\text { distributed } \\
\text { 1.7-2.7 million } \\
\text { ha } \\
\text { Regression }\end{array}$ & $\begin{array}{c}\text { Cork, } \\
\text { Acorns, } \\
\text { Grazing, } \\
\text { Food for } \\
\text { livestock, } \\
\text { Wood for } \\
\text { lumber and fuel }\end{array}$ & $\begin{array}{c}\text { Regulation } \\
\text { Provisioning } \\
\text { Habitat } \\
\text { Cultural }\end{array}$ & $\begin{array}{l}\text { High in North } \\
\text { and South } \\
\text { Deforestation } \\
\text { Climate Change }\end{array}$ \\
\hline $\begin{array}{l}\text { Pinus } \\
\text { halepensis } \\
\text { Aleppo } \\
\text { pine }\end{array}$ & evergreen & $\begin{array}{l}\text { Strictly mediterranean } \\
\text { (thermomediterranean } \\
\text { and } \\
\text { mesomediterranean) }\end{array}$ & $\begin{array}{c}\text { Widely } \\
\text { distributed } \\
3.5 \text { million ha } \\
\text { Extension }\end{array}$ & $\begin{array}{c}\text { Wood for paper } \\
\text { pulp and fuel }\end{array}$ & $\begin{array}{c}\text { Regulation } \\
\text { Provisioning } \\
\text { Habitat } \\
\text { Cultural }\end{array}$ & $\begin{array}{c}\text { Low } \\
\text { Pioneer species } \\
\text { spreading on } \\
\text { abandoned lands }\end{array}$ \\
\hline $\begin{array}{c}\text { Juniperus } \\
\text { thurifera } \\
\text { Thuriferous } \\
\text { Juniper }\end{array}$ & evergreen & $\begin{array}{l}\text { Western part of the } \\
\text { Mediterranean } \\
\text { (supramediterranean, } \\
\text { mountain and } \\
\text { oromediterranean) }\end{array}$ & $\begin{array}{c}\text { Restricted area } \\
\pm 200.000 \text { ha } \\
\text { Regression in } \\
\text { South } \\
\text { Stability in } \\
\text { North }\end{array}$ & $\begin{array}{l}\text { Wood for } \\
\text { lumber and fuel } \\
\text { Food for } \\
\text { livestock, } \\
\text { Extraction of } \\
\text { oil }\end{array}$ & $\begin{array}{c}\text { Regulation } \\
\text { Provisioning } \\
\text { Habitat } \\
\text { Cultural }\end{array}$ & $\begin{array}{c}\text { High } \\
\text { Overharvesting } \\
\text { Climate Change }\end{array}$ \\
\hline
\end{tabular}

